\title{
КОНТРАКТЫ НА ОКАЗАНИЕ УСЛУГ ПО ОТЛОВУ И СОДЕРЖАНИЮ БЕЗНАДЗОРНЫХ ЖИВОТНЫХ В ГОРОДАХ РФ: РАСХОДЫ И РЕЗУЛЬТАТЫ
}

\section{CONTRACTS FOR THE PROVISION OF SERVICES FOR TRAPPING AND KEEPING STRAY ANIMALS IN CITIES OF THE RUSSIAN FEDERATION: COSTS AND RESULTS}

I. Rusakova

Summary. The relevance of the problem of the presence of stray animals in urban areas is confirmed by publications in the media and federal legislation, and is discussed at meetings of the municipal and regional levels. As experience and statistics show, measures to regulate the number of street animals, financed mainly from the state budget, do not lead to a solution to the problem. The article analyzes the contracts for the provision of services for trapping and keeping stray animals in a number of Russian cities, draws conclusions about the degree of effectiveness and justification of the costs of the measures taken, and the reasons for the unsatisfactory results.

Keywords: number of stray animals, procurement, trapping and keeping, procurement documentation.

\section{Введение}

$\Pi$ роблема наличия бродячих (безнадзорных) животных, в частности, собак, в городской среде - одна из тех, решить которые в полной мере не удается в течение долгого времени. Среди причин на одном из первых мест стоит отсутствие точной и регулярно обновляемой информации о фактической численности бродячих животных на территории городов. Это приводит в одних случаях к недостаточному финансированию мероприятий по регулированию численности безнадзорных животных, в других, - к необоснованным расходам на упомянутые мероприятия. Проблема учета численности бродячих животных регулярно поднимается в средствах массовой информации [4-8] и в научных работах [см., например, 1, 2, 3]. С 1 января 2020 г. вступил в силу принятый в 2018 году закон «Об ответственном обращении с животными и о внесении изменений в отдельные законодательные акты Российской Федерации» от 27.12.2018 N498-Ф3, устанавливающий дополнительные требования к поставщикам. Анализ содержания нескольких десятков контрактов за 2017 год показал, что

\author{
Русакова Инна Викторовна \\ Аспирант, Санкт-Петербургский государственный \\ экономический университет \\ rusakova_i@mail.ru
}

Аннотация. Актуальность проблемы наличия безнадзорных животных на территориях городов подтверждается публикациями в средствах массовой информации и федеральным законодательством, обсуждается на совещаниях муниципального и регионального уровня. Как показывает опыт и статистические данные, мероприятия по регулированию численности безнадзорных животных, финансируемые в основном из государственного бюджета, не приводят к решению проблемы. В статье анализируются контракты на оказание услуг по отлову и содержанию безнадзорных животных в ряде российских городов, делаются выводы о степени обоснованности и результативности расходов на проводимые мероприятия, и о причинах неудовлетворительных результатов.

Ключевые слова: численность безнадзорных животных, закупки, отлов и содержание, закупочная документация. одна из причин неисполнения - несоответствие поставщиков установленным требованиям. Время покажет, как изменится ситуация в сфере закупок услуг по регулированию численности безнадзорных животных в соответствии с принятым законом и усложнением условий. Подготовка к проведению мероприятий с учетом положений закона, направленного на гуманное регулирование численности безнадзорных животных, требует знания количества бродячих животных в конкретном населенном пункте. Иначе невозможно спланировать требуемое количество мест в приютах, ветеринарных препаратов и оборудования. В данной статье проводятся сопоставления имеющихся результатов подсчета бродячих животных в российских городах с численностью, заявленной к отлову, и суммами бюджетных ассигнований, выделенных на мероприятия по регулированию их численности.

\section{Теория}

Объект исследования - тендерная документация на мероприятия по отлову и содержанию безнадзорных 
Таблица 1. Сведения о количестве безнадзорных животных, заявленном к отлову, и суммах, выделенных на отлов, стерилизацию и содержание, РФ, 2017

\begin{tabular}{|c|c|c|c|}
\hline № $\Pi / n$ & Город & $\begin{array}{l}\text { Число безнадзорных } \\
\text { животных, заявленное } \\
\text { к отлову, гол. }\end{array}$ & Сумма контракта, руб. \\
\hline 1. & Барнаул & 1118 & 1959309 \\
\hline 2. & Благовещенск & 120 & 197136 \\
\hline 3. & Брянск & 668 & 438923 \\
\hline 4. & Великий Новгород & 282 & 2276101 \\
\hline 5. & Владимир & 1032 & 6561115 \\
\hline 6. & Воронеж & 93 & 524021 \\
\hline 7. & Иваново & 277 & 1537730 \\
\hline 8. & Ижевск & 2710 & 2168000 \\
\hline 9. & Иркутск & 1943 & 4841375 \\
\hline 10. & Калуга & 340 & 1605451 \\
\hline 11. & Кемерово & 452 & 1730641 \\
\hline 12. & Киров & 1889 & 3013200 \\
\hline 13. & Красноярск & 1083 & 3991778 \\
\hline 14. & Курган & 146 & 367584 \\
\hline 15. & Липецк & 176 & 3558926 \\
\hline 16. & Нижний Новгород & 4678 & 14580117 \\
\hline 17. & Орел & 228 & 747213 \\
\hline 18. & Оренбург & 57 & 178647 \\
\hline 19. & Пенза & 242 & 540120 \\
\hline 20. & Ростов-на Дону & 799 & 1549524 \\
\hline 21. & Салехард & 68 & 320300 \\
\hline 22. & Сыктывкар & 332 & 2611207 \\
\hline 23. & Tверь & 227 & 678606 \\
\hline 24. & Тольятти & 801 & 2002500 \\
\hline 25. & Ульяновск & 1831 & 1108300 \\
\hline 26. & Уфа & 11352 & 12035469 \\
\hline 27. & Хабаровск & 2656 & 3541965 \\
\hline 28. & Якутск & 600 & 356000 \\
\hline \multirow[t]{2}{*}{29.} & Ярославль & 1089 & 2992730 \\
\hline & ИТОГО & 37289 & 78013988 \\
\hline
\end{tabular}

Составлено по данным ЕИС госзакупок [9]

животных в городах Российской Федерации за 2017 гг. Предмет исследования - количество отловленных животных и суммы финансирования мероприятий по отлову. Цель исследования состоит в оценке обоснованности финансирования проводимых в российских городах мероприятий по регулированию численности безнадзорных животных. Для проведения оценки по каждому отобранному городу необходимо определить соотношение численности, заявленной к отлову, и фактической численности бродячих животных на территории населенного пункта, а затем установить связь размера сумм, выделенных на финансирование мероприятий, и численности животных, выделенной к отлову. Под фактической численностью бродячих животных понимается та, которая фигурирует в отчетах официальных лиц и ссылающиеся на них средствах массовой информации.
Исследование основано на данных цензовой группы городов, использовании табличного и графического методов, корреляционно-регрессионного анализа.

\section{$\triangle$ анные и мето $ы$}

В статье использованы данные по заключенным контрактам в 2017 году в городах Российской Федерации на услуги по отлову и содержанию безнадзорных (бродячих, бездомных) животных. В выборку включены преимущественно административные центры, поскольку исследуется именно городская ситуация, которая существенно отличается от сельской, как в содержании домашних животных, так и в регулировании численности бездомных животных. Тендерная документация для анализа бралась с официального сайта государствен- 
Таблица 2.

\begin{tabular}{|c|c|c|c|c|c|c|}
\hline № п/п & Город & $\begin{array}{l}\text { Сумма на меро- } \\
\text { приятия по ре- } \\
\text { гулированию } \\
\text { численности } \\
\text { безнадзорных } \\
\text { животных, руб. }\end{array}$ & Отлов, гол. & $\begin{array}{l}\text { Официальная } \\
\text { численность } \\
\text { безнадзорных } \\
\text { животных, гол. }\end{array}$ & $\begin{array}{l}\text { Процент от- } \\
\text { лова от офи- } \\
\text { циальной } \\
\text { численности }\end{array}$ & $\begin{array}{l}\text { Сумма, } \\
\text { выделенная } \\
\text { на отлов } 1 \\
\text { головы, руб }\end{array}$ \\
\hline 1 & Благовещенск & 197136 & 120 & 1300 & 9,23 & 1642,80 \\
\hline 2 & Владимир & 6561115 & 1032 & 500 & 206,40 & 6357,67 \\
\hline 3 & Воронеж & 524021 & 93 & 3500 & 2,66 & 5634,63 \\
\hline 4 & Иркутск & 4841375 & 1943 & 700 & 277,57 & 2491,70 \\
\hline 5 & Кемерово & 1730641 & 452 & 500 & 90,40 & 3828,85 \\
\hline 6 & Красноярск & 3991778 & 1083 & 15000 & 7,22 & 3685,85 \\
\hline 7 & Магадан & 3558926 & 176 & 1700 & 10,35 & 20221,17 \\
\hline 8 & Нижний Новгород & 14580117 & 4678 & 4700 & 99,53 & 3116,74 \\
\hline 9 & Ростов-на Дону & 1549524 & 799 & 4500 & 17,76 & 1939,33 \\
\hline 10 & Салехард & 320300 & 68 & 500 & 13,60 & 4710,29 \\
\hline 11 & Тольятти & 2002500 & 801 & 3500 & 22,89 & 2500,00 \\
\hline \multirow[t]{2}{*}{12} & Хабаровск & 3541965 & 2656 & 3000 & 88,53 & 1333,57 \\
\hline & ИТОГО & 43399398 & 13901 & 39400 & & \\
\hline
\end{tabular}

Данные о численности безнадзорных животных, количестве их, запланированном к отлову, и суммах, выделенных на мероприятия по регулированию численности безнадзорных животных. РФ, 2017 г.

Составлено по данным СМИ и ЕИС госзакупок [4-16].

ных закупок за 2017 год [9]. Поиск закупок проведен, по ключевым словам, «отлов, безнадзорных животных, город». Период 2017 г выбран по следующим причинам. В 2019 году в России проводился чемпионат мира по футболу, в связи с чем мероприятия по отлову безнадзорных животных были в 2018 году усилены, и объем их финансирования не может рассматриваться в качестве типичного. По этой же причине были отвергнуты данные 2019 года.

В найденных сведениях о закупках устанавливалось, был ли заключен контракт; в документах по заключенным контрактам выделялись сведения об исполнении. Таким образом была сформирована совокупность из 29 городов, которая составила основу для первичного анализа (табл. 1).

В число заявленных к отлову животных данные по г. Липецку включены по факту исполненных контрактов, так как в закупочной документации сказано, что предварительно количество их определить невозможHO.

Для дальнейшего исследования и получения более обоснованных данных была сформирована дополнительная совокупность, в которую вошли города - преимущественно административные центры, где имелись данные о численности безнадзорных животных за 20162017 гг., опубликованные в открытых источниках: докладах ответственных лиц в СМИ, отчетах управлений ветеринарии по административным округам и др. Полученная совокупность составила 12 городов (табл. 2).

\section{Анализ}

Корреляционно-регрессионный анализ совокупности из 29 городов свидетельствует о наличии связи средней тесноты. Уравнение регрессии (рис. 1) показывает, что при увеличении числа отловленных животных на одну особь расходы на отлов увеличатся в среднем на 1,19 тыс. руб. На основании значения t-статистики $(t=6,58$, выше табличного $t=2,05)$, а также критерия Фишера ( $F=43,4$ больше $\left.F_{\text {табл }}=4,21\right)$ при заданном уровне значимости 0,05 считаем уравнение регрессии значимым.

Расположение точек на поле корреляции свидетельствует о прямой связи между показателями. Однородность совокупности нарушают два нетипичных значения заявленной к отлову численности безнадзорных животных. Эти величины относятся к городам Нижний Новгород и Уфа - 4678 и 11352 голов, соответственно. Для выявления возможных причин выбросов рассмотрим подробнее материалы закупок этих городов.

По Нижнему Новгороду существуют официальные данные об общей численности бродячих животных, и она практически совпадает с заявленной к отлову 4700 голов [14]. То есть администрация города организовала закупку с целью отловить и стерилизовать либо 


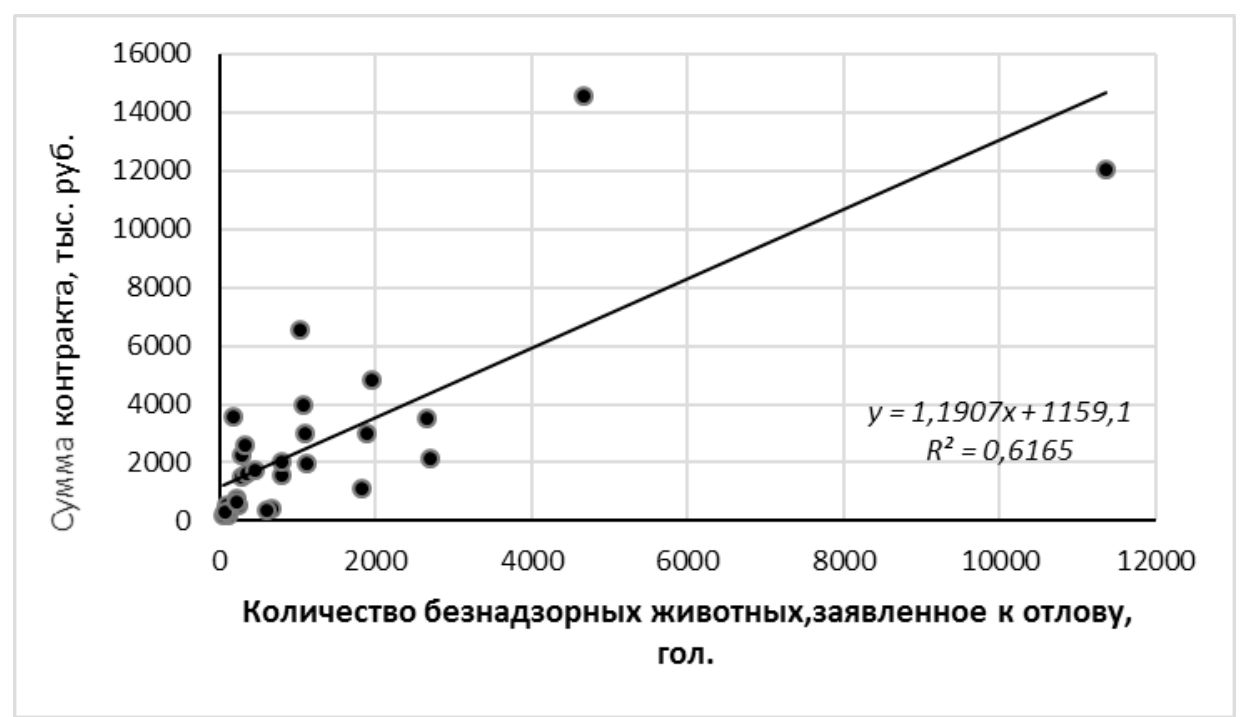

Рис. 1. Поле корреляции между количеством безнадзорных животных, заявленных к отлову, и суммами контракта на мероприятия по регулированию численности безнадзорных животных по 29 городам РФ, 2017 г.

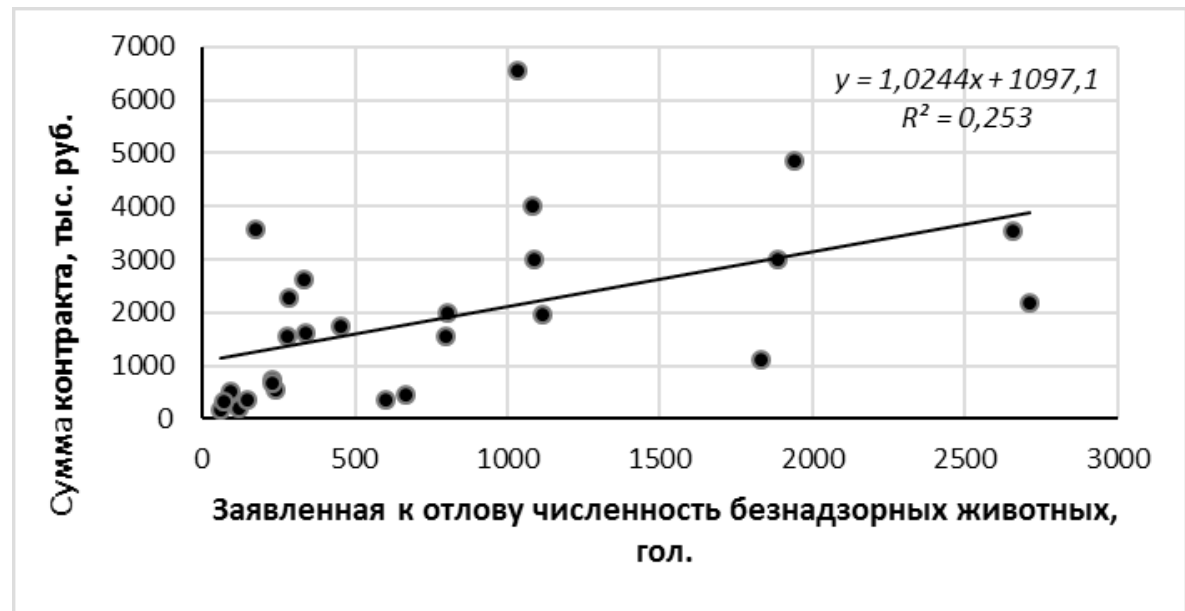

Рис. 2. Поле корреляции между количеством безнадзорных животных, заявленных к отлову, и суммами контрактов на мероприятия по регулированию численности безнадзорных животных (27 городов, без аномальных значений), РФ, 2017 г.

подвергнуть эвтаназии абсолютно всю существующую популяцию на своей территории. Судя по актам исполнения работ, это ей удалось. Однако, сведения, содержащиеся в ЕИС госзакупок, это опровергают: на 2018 год снова был заключен контракт на отлов, хотя уже меньшего числа голов (3752 голов) на сумму 11532945 руб. [17]. Откуда взялось это количество, если на конец 2017 г., согласно акту о выполненных работах, популяция была ликвидирована? Возможные ответы: 1) неверно рассчитано общее число бродячих животных на 2017 год; 2) число к отлову на 2018 год не имеет обоснования, взято по опыту предыдущего года, без учета утраты способности популяции к самовосстановлению [1]. В любом случае очевидно, что потраченные 14,6 млн. руб. не решили проблему.

По Уфе официальных данных о численности бродячих животных на 2017 год найти не удалось. Согласно закупочной документации, контракт заключен на отлов 8360 собак и 2992 кошек на сумму около 12 млн. руб. Однако, согласно актам выполненных работ, отловлено 3164 собаки, из которых абсолютное большинство уничтожено, и лишь 26 после содержания в пункте передержки были выпущены в среду обитания или переданы владельцам, новым или прежним. Контракт был исполнен на сумму 1903274 руб., то есть на сумму, примерно в 6 


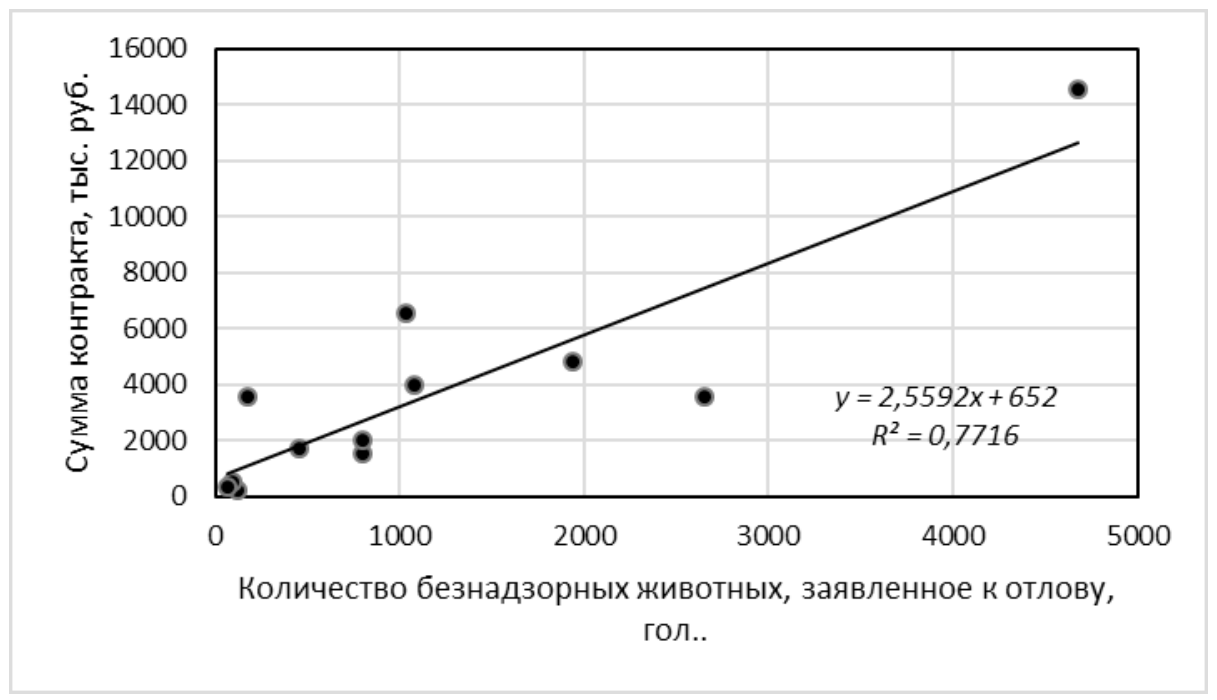

Рис. 3. Поле корреляции количества безнадзорных животных, заявленного к отлову, и суммой контракта на мероприятия по регулированию численности безнадзорных животных в 12 городах РФ с известной численностью бродячих животных за 2017 г.

раз меньшую заявленной. Исполнение было прекращено по соглашению сторон в установленный срок. Это может говорить о том, что число животных к отлову было завышено.

Обобщив результаты, можем сказать, что в обоих случаях наблюдаются признаки некорректности изначальных данных о численности безнадзорных животных в городе.

Исключив Нижний Новгород и Уфу из совокупности 1, получим совокупность из 27 городов. Корреляционное поле по 27 городам представлено на рис. 2.

Несмотря на снижение тесноты связи $\left(R^{2}=0,25\right)$, полученное уравнение остается статистически значимым $\left(\mathrm{F}=8,46\right.$ больше $\left.\mathrm{F}_{\text {табл }}=4,24\right)$ при заданном уровне значимости 0,05.

По результатам корреляционно-регрессионного анализа данных 12 городов с известной численностью безнадзорных животных (табл. 2) выявлена статистически значимая линейная связь между числом отловленных животных и суммами средств на мероприятия по регулированию их численности (рис. 3).

Довольно высокое значение $R^{2}(0,77)$ говорит о том, что выделение средств на отлов и содержание безнадзорных животных имеет примерно одинаковое во всех городах обоснование. Интерпретируя коэффициент регрессии, можно сказать, что увеличение заявленного к отлову числа количества животных на одну особь приводит к увеличению расходов на отлов в среднем на 2,56 тыс. руб. Корреляцию можно считать тесной. На основании значения $\mathrm{t}$-статистики $(\mathrm{t}=5,81$, что больше табличного значения 1,8), а также критерия Фишера $\left(F=33,79\right.$ больше $\left.F_{\text {табл }}=4,96\right)$ при заданном уровне значимости 0,05 уравнение регрессии является значимым.

Дальнейший анализ совокупности не выявил корреляции между размером выделенной суммы и фактической численностью безнадзорных животных. Заявленное к отлову количество животных с фактической численностью безнадзорных животных также не коррелирует. Возникает вопрос, из чего исходят решения о выделении средств к отлову?

Рассматривая соотношение отловленных животных с общим фактическим количеством, можно заключить следующее.

Во-первых, процент отлова сильно варьирует. Вероятно, численность заявленных к отлову животных зависит скорее от выделенных средств, чем от расчетной необходимой численности отловленных безнадзорных животных. В семи из двенадцати исследуемых городов процент отлова не превышает четверти от общей численности, тогда как в двух городах, напротив, число к отлову в два раза превышает официальную численность, что указывает на некорректность официальных данных. Во-вторых, суммы на мероприятия по регулированию численности безнадзорных животных также весьма различаются. По всем административным центрам средняя величина расходов на одну голову составляет 2092 руб. Несколько выше эта сумма в совокупности, где присутствуют данные о количестве 
Таблица 3. Распределение расходов в актах оказанных услуг исполненных контрактов

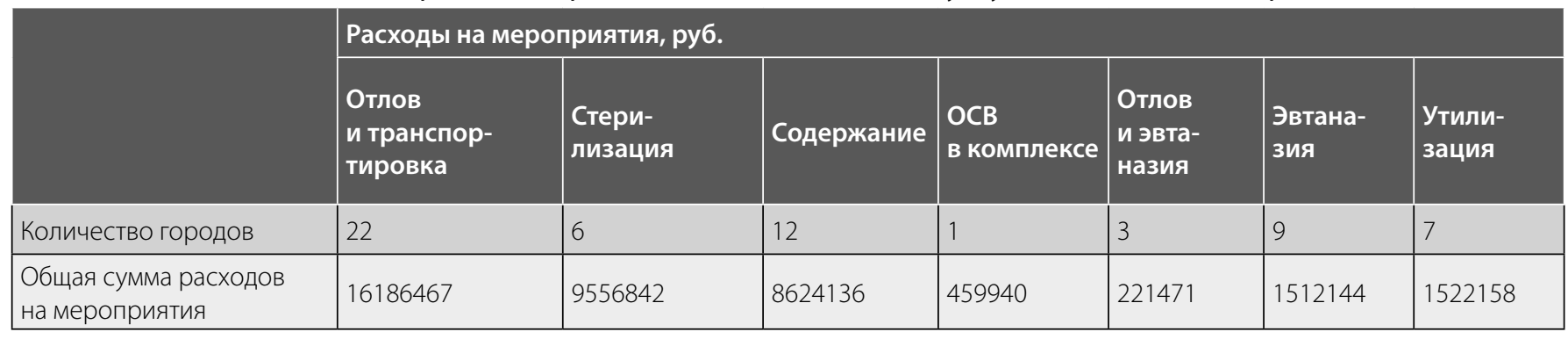

Составлено по данным ЕИС госзакупок [9]

бродячих животных - 3122 руб. Можно предположить, что в городах, где ведется учет численности бродячих животных, меры по ее регулированию направлены не только на отлов и уничтожение, но и на содержание животных.

На основе актов выполненных работ была сделана попытка детализации расходов с целью рассчитать долю расходов на мероприятия, направленные на сохранение жизни отловленным животным (содержание в пункте временного содержания, осмотр ветеринаром, стерилизация, биркование) и мероприятия по эвтаназии и утилизации животных. В совокупность включены 23 города, в контрактах которых определены суммы на различные виды услуг. Расчет показал, что расходы на мероприятия по сохранению жизни животным составляют около 7,33 млн. руб., то есть 30 процентов от общей суммы исполненных контрактов. Однако следует учесть, что большинство актов приемки-сдачи услуг в закупочной документации не содержат расшифровки расходов. В подавляющем большинстве актов указано «отлов и транспортировка», без уточнения. Суммы на отлов и транспортировку одной особи колеблются от 160 до 700 руб. Создается впечатление, что все мероприятия сводятся к перевозу собак с одного места на другое. Судя по тому, что проблема сокращения численности бродячих животных в городах год от года не решается, в этом предположении есть доля правды.

По видам указанных в актах мероприятий количество городов распределялись следующим образом (табл. 3):

Из таблицы 3 очевидно, что выявить точные суммы на проведение того или иного мероприятия (то есть отделить эвтаназию от отлова, либо отлов от содержания и т.д.) не представляется возможным, так как в закупочной документации зачастую две-три услуги объединены в одну. Представленные сведения позволяют сделать вывод о недостаточной структурированности расходов на мероприятия по регулированию численности бродячих животных, что не дает возможности провести детальный анализ проведенных мероприятий.
Данные закупочной документации отдельных городов указывают на различия в подходах к обоснованию финансирования мероприятий по регулированию численности бродячих животных. Например, в тендерной документации г. Липецка данные о численности безнадзорных животных, как уже отмечалось, отсутствуют, и в проекте двух контрактов прямо указано, что объем работ невозможно определить, а запрошенные суммы по этим контрактам составляют 2195000 руб. и 3800000 руб., соответственно. При этом на городском портале Липецка со ссылкой на сообщение мэрии называется число бродячих животных: 1 тысяча голов, и сообщается, что отлов их бюджету Липецка обойдется в несколько сотен тысяч рублей [7]. Действительно, в системе госзакупок размещено несколько контрактов и два акта выполненных работ, согласно которым всего отловлено 41 животное и подобрано 39 трупов павших животных. Остальных актов в системе найти не удалось, можно лишь сказать, что в целом на мероприятия было выделено около 1,75 млн., однако один из контрактов был расторгнут в связи с отсутствием у поставщика условий для содержания животных. Далее, в 2017 году согласно актам выполненных работ в Липецке отловлено 5676 животных, то есть в 5,6 раз больше их общего количества на территории города, согласно официальным данным. Если это соответствует действительности, то учет бродячих животных, на результаты которого ссылались ранее представители мэрии, вероятно, осуществлялся некорректно.

В контрактах г.Владимира услуги расписаны подробно. Но согласно закупочной документации и отчету администрации по итогам 2017 года оказалось, что отловленное число бродячих животных в два раза превышает их заявленную общую численность на территории города [4].

В целом, по итогам анализа 62 контрактов, заключенных в 29 городах РФ следует отметить, что доля контрактов, в которых в услуги включена стерилизация и вакцинация, от общего числа контрактов составляет 18\%. В остальных контрактах акты либо включают только отлов, передержку и эвтаназию, либо только отлов и транспортировка, либо вовсе не содержат расшифров- 
ки оказанных услуг. Исполнение ряда контрактов прекращалось досрочно по таким причинам, как отсутствие у поставщика необходимых для исполнения условий, в частности, пунктов передержки или по соглашению сторон, в связи с отсутствием потребности в дальнейших услугах. В среднем на 1 особь выделялось около 2 тыс. руб., однако эта величина не отражает фактических расходов и потребности в конкретных мероприятиях.

\section{Результаты}

На основе результатов анализа двух совокупностей можно сделать следующие выводы. Документация тех городов, по которым известна ориентировочная численность бродячих животных, отличается более высокой степенью обоснованности расходов. То есть там, где ведется учет бродячих животных, наблюдается более ответственный подход к составлению закупочной документации на их отлов. Можно также отметить, что в городах, где ведется учет животных, процент мероприятий, направленных на сохранение жизни отловленных животных, выше, чем в остальных.

Отсутствие в контрактах требований к детализации расходов на мероприятия по регулированию численности бродячих животных не позволяет в полной мере проанализировать их и определить объем потребности в той или иной услуге в этой сфере, а также сравнить структуру расходов в разных регионах и выявить региональные особенности.

Численность животных, заявленная к отлову, в ряде случаев превышает фактическую, что говорит о рассогласованности работы служб, которые занимаются учетом численности животных, со службами, отвечающими за регулирование их численности. Очевидна потребность в разработке и внедрении единой методики оценки численности бродячих животных.

Процент заявленной к отлову численности животных от общей в большинстве городов невысок, тогда как уста- новлено, что для сокращения популяции, то есть утраты ею способности к самовосстановлению, необходимо сократить численность бродячих животных на 70-80\% [1]. Таким образом, мероприятия по отлову безнадзорных животных, по крайней мере, в половине российских городов изначально не направлены на сокращение популяции, а значит, нельзя говорить об их результативности. Кроме того, не имея начального значения численности безнадзорных животных на территории, невозможно доказать результативность проведенных мероприятий.

\section{Зак^ючение}

Проблема учета и регулирования безнадзорных животных практически не исследуется экономистами, хотя имеются все основания рассматривать ее как значимое социально-экономическое явление. Расходование бюджетных средств на ее решение не приводит к ощутимому результату. Негуманность и нерезультативность проводимых мероприятий, как правило, вызывает общественный резонанс, осознание необходимости изменения существующей практики на законодательном уровне. Среди причин неэффективности принимаемых мер следует назвать отсутствие контроля за исполнением контрактов подрядчиками, а также неприемлемость в российских условиях западной практики (кратковременное содержание в приюте и умерщвление при невостребованности). Первым шагом к исправлению ситуации должна стать организация регулярного учета безнадзорных животных по единой методике.

Вопрос об организации учета и получения корректных данных о численности безнадзорных животных поднимался в работах отечественных исследователей в различных областях науки. Это говорит о том, что проблема наличия безнадзорных животных в городской среде - междисциплинарная. Для решения ее требуется объединение усилий ветеринаров, экологов, социологов, экономистов, и, только осознав масштаб заявленной проблемы, современное общество сможет найти пути ее решения.

\section{ЛИТЕРАТУРА}

1. Рыбалко В. А. Обзор мирового опыта в решении проблемы бездомных животных [Текст] / В. А. Рыбалко // Ветеринарная патология.— $2006 .-$ № 2 (17).- - C. 12-18.

2. Сабирьянов А. Ф. Государственное регулирование отлова и содержания безнадзорных животных [Текст] / А. Ф. Сабирьянов // Ученые записки Казанской государственной академии ветеринарной медицины им. Н. Э. Баумана. - 2018. - Т. 234. — № .2.— С. 166-169

3. Темникова А. И. Регистрация домашних животных как эффективный метод правового регулирования проблемы безнадзорности животных [Текст] / А. И. Темникова // Правовая политика и правовая жизнь.—2016. — № 1.—C. 55-59

4. Александрова В. Собачий вопрос [Электронный ресурс] / В. Александрова // Зеб: ра. Новостной портал г. Владимира (дата публикации 21.11.2017).URL: https://zebra-tv.ru/novosti/jizn/sobachiy-vopros/ (Дата обращения: 02.12.2019);

5. В 2016 году в Магадане было умерщвлено 1707 безнадзорных животных [Электронный ресурс] // Колыма.ру. (дата публикации 08.05.2017) URL: http:// www.kolyma.ru/index.php?newsid=67247 (Дата обращения: 02.12.2019); 
6. В Благовещенске вдвое снизилась численность бродячих собак [Электронный ресурс] // Амурская правда. Дата публикации 20.08.2015 URL: https://www. ampravda.ru/2015/08/20/059806.html (Дата обращения: 02.12.2019);

7. В Липецке собираются уничтожить тысячу бездомных кошек и собак. - Городской портал Липецка [Электронный ресурс]. Дата публикации 09.02.2016 URL:URL:http://cod48.ru/novosti-kompanij/v-lipecke-sobirayutsya-unichtozhit-tysyachu-bezdomnyx-koshek-i-sobak-12570.html (Дата 0бращения 12.01.2020);

8. В ожидании зоозакона [Электронный ресурс] //Кузбасс. Областная газета. Дата публикации 27.09.2017 URL: http://kuzbass85.ru/2017/09/27/v-0zhidaniizoozakona/ (Дата обращения: 02.12.2019)

9. Единая информационная система госзакупок [Электронный ресурс] URL: www.zakupki.gov.ru (Дата обращения: 02.12.2019)

10. В Салехарде 500 бездомных собак. Бороться за безопасность должны все вместе [Электронный ресурс] // Север-пресс. Информационное агентство. Дата публикации 03.04.2018 URL: http://sever-press.ru/obshchestvo/bezopasnost/item/38842-v-salekharde-500-bezdomnykh-sobak-borotsya-za-bezopasnostdolzhny-vse-vmeste (Дата обращения: 02.12.2019);

11. К чемпионату мира по футболу города зачищают от собак [Электронный ресурс] //K-9.ru. Дата публикации 28.02.2018 URL: http://k-9.ru/archives/1478 (Дата обращения: 02.12.2019);

12. Ланская Е. Бюджет финансирует живодеров. [Электронный ресурс] // Красноярская версия Дата публикации 22.07.2015 URL: http://www.centrosib. info/2015/07/22/byudzhet-finansiruet-zhivodyorov/ (Дата обращения: 02.12.2019);

13. Молотов М. Хабаровский следком нашел решение катастрофической ситуации в городе с безнадзорными животными [Электронный ресурс] // Новости Хабаровска на DVHab.ru Дата публикации 12.05.2017. URL: https://www.dvnovosti.ru/khab/2017/05/12/66288/ (Дата обращения: 02.12.2019);

14. Мэрия Нижнего Новгорода отрицает причастность к работе «Концлагеря для собак» [Электронный ресурс] //NN.RU Дата публикации 23.01.2017. URL: https://www.nn.ru/news/more/meriya_nizhnego_novgoroda_otritsaet_prichastnost_k_rabote_kontslagerya_dlya_sobak/50244041/ (Дата обращения: 02.12.2019);

15. На улицах Воронежа продолжают оставаться около 3250 безнадзорных животных [Электронный ресурс] // Коммуна. Новостной портал Воронежа и Воронежской области. Дата публикации 15.11.2017 URL: https://communa.ru/ekologiya/na_ulitsakh_voronezha_prodolzhayut_0stavatsya_0kolo_3250_ beznadzornykh_zhivotnykh/ (Дата обращения: 02.12.2019);

16. Служба ветеринарии Иркутской области. Официальный сайт. [Электронный ресурc] URL: https://irkobl.ru/sites/vet/brodiagi/ (Дата 0бращения: 01.02.2017)

17. ИКЗ 183525300103652604500400010177500244, Единая информационная система госзакупок [Электронный ресурc] URL: www.zakupki.gov.ru (Дата 0бращения: 02.12.2019);

(с) Русакова Инна Викторовна ( rusakova_i@mail.ru).

Журнал «Современная наука: актуальные проблемы теории и практики»

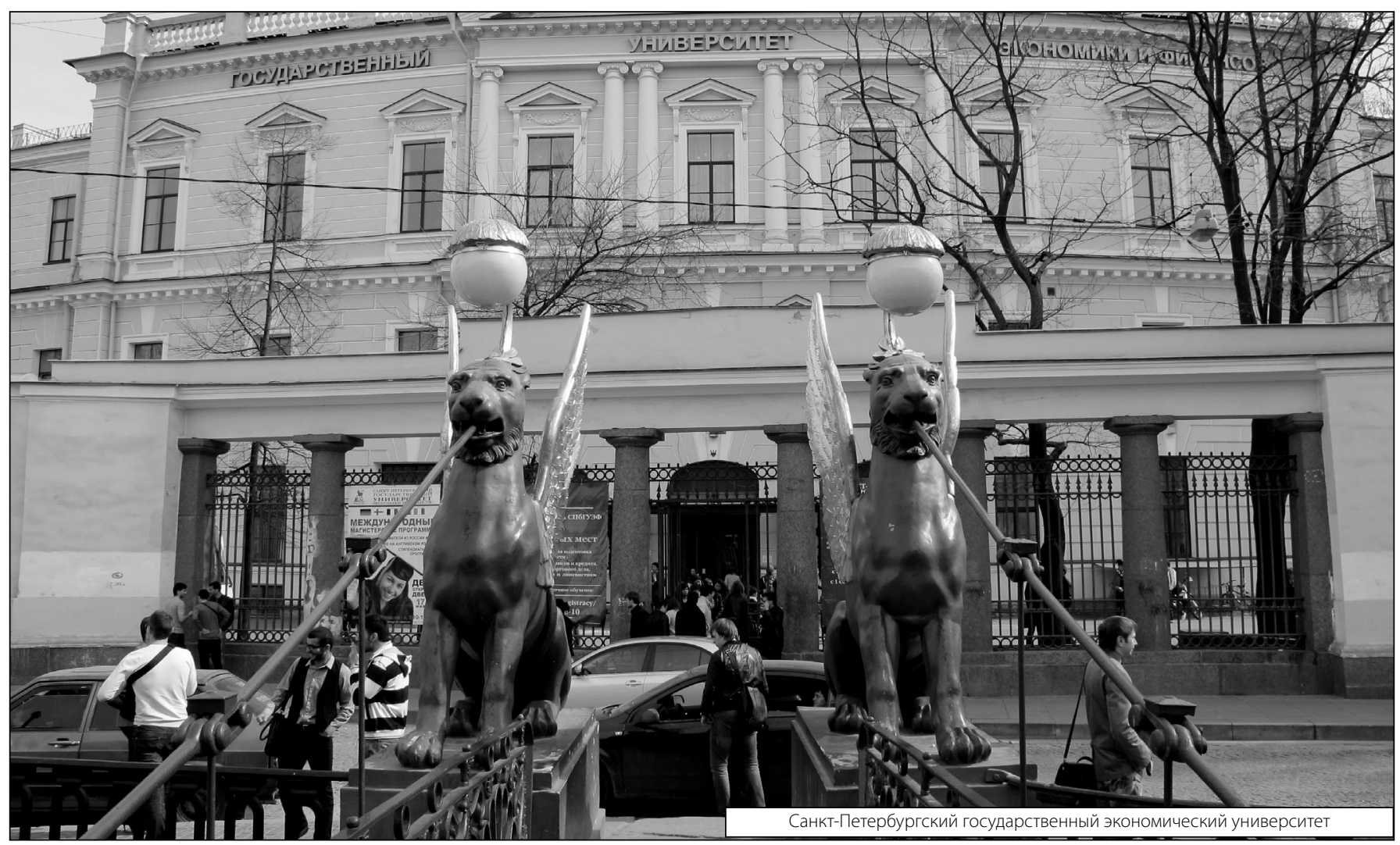

